\title{
Pengaruh Fitur E-Commerce Terhadap Keputusan Pembelian Konsumen di Masa Pandemi Covid-19
}

\author{
Galang Nusantara Achmad1), Salsabilah Shofiyatul Jannah²) \\ 1), 2) Universitas Jember, Jember, Indonesia \\ Corresponding author: galanngna@gmail.com
}

\begin{abstract}
:
E-Commerce during a pandemic is increasingly showing its rapid acceleration. It is undeniable that currently E-Commerce is an alternative choice for people to shop safely during a pandemic. One of the supports for E-Commerce activities is the presence of various online shopping applications that make it easy for consumers to shop online. This resulted in very tight competition between application companies. Even though the online shopping application has the same function, it includes features that work differently. These features can influence consumer behavior in choosing applications to use. The application features then become an important aspect that must be considered by companies. This research was conducted through a quantitative method approach by means of a simple linear regression test. Taking the research sample population using purposive sampling technique. From the research results it is known that the value of $\mathrm{F}$ count $=17.251$ with a significance level of $0.000<0.05$, so there is an influence between the E-Commerce Application Feature variable $(\mathrm{X})$ on the Purchasing Decision variabel $(\mathrm{Y})$. The magnitude of the correlation value (R) is 0.526 and produces a coefficient of determination (R Square) of 0.277 , which means that the influence of the independent variabel (E-Commerce Application Features) on the dependent variable (Purchase Decision) is $27.7 \%$. From the results of this research, it can be concluded that the features in the application affect consumer behavior in making purchase decisions.
\end{abstract}

Keywords: Application Features; E-Commerce; Purchase Decision

\begin{abstract}
Abstrak:
E-Commerce di masa pandemi semakin menunjukkan akselerasinya yang begitu pesat. Tak dapat dipungkiri saat ini E-Commerce menjadi alternatif pilihan masyarakat untuk berbelanja secara aman di masa pandemi. Salah satu penunjang kegiatan E-Commerce adalah hadirnya berbagai aplikasi belanja online yang memberikan kemudahan pada konsumen dalam berbelanja online. Hal tersebut mengakibatkan persaingan antar perusahaan aplikasi menjadi sangat ketat. Meskipun aplikasi belanja online memiliki fungsi yang sama akan tetapi didalamnya terdapat fitur-fitur dengan cara kerja yang berbeda. Fitur-fitur tersebut dapat mempengaruhi perilaku konsumen dalam memilih aplikasi yang akan digunakan. Fitur aplikasi kemudian menjadi aspek penting yang harus diperhatikan oleh perusahaan. Penelitan ini dilakukan melalui pendekatan metode kuantitatif dengan cara uji regresi linear sederhana. Pengambilan populasi sampel penelitian menggunakan teknik purposive sampling. Dari hasil penelitian diketahui bahwa nilai $\mathrm{F}$ hitung $=17,251$ dengan tingkat signifikansi sebesar $0,000<0,05$, maka terdapat pengaruh antara variabel Fitur Aplikasi $E$ Commerce $(\mathrm{X})$ terhadap variabel Keputusan Pembelian $(\mathrm{Y})$. Adapun besarnya nilai korelasi (R) yaitu sebesar 0,526 dan menghasilkan nilai koefisien determinasi (R Square) sebesar 0,277, yang berarti bahwa besarnya pengaruh variabel bebas (Fitur Aplikasi E-Commerce) terhadap variabel terikat (Keputusan Pembelian) adalah sebesar 27,7\%. Dari hasil riset tersebut dapat disimpulkan bahwa fitur dalam aplikasi mempengaruhi perilaku konsumen dalam memutuskan pembelian.
\end{abstract}

Kata Kunci: E-Commerce; Fitur Aplikasi; Keputusan Pembelian. 


\section{PENDAHULUAN}

Digitalisasi di era modern semakin bertumbuh hingga menjadi salah satu prospek bisnis yang menjanjikan. Salah satu peluang bisnis digital yang sedang naik daun adalah ECommerce. Memparafrase dari (Rakhmawati et al., 2021) E-Commerce adalah sebuah kegiatan membeli atau menjual produk-produk secara daring oleh konsumen dan dari perusahaan ke perusahaan dengan komputer atau alat elektronik sebagai perantara transaksi bisnis. E-Commerce yang secara sederhana diartikan sebagai jual beli secara online dewasa ini semakin familiar dan sudah menjadi bagian gaya hidup masyarakat. Terlebih di masa pandemi yang mengharuskan masyarakat membatasi aktivitas diluar rumah mengakibatkan E-Commerce menjadi salah satu alternatif terbaik dalam melakukan aktivitas jual beli secara tidak langsung. E-Commerce di masa pandemi semakin menunjukkan akselerasinya, berdasarkan riset yang dilakukan (Kusumastuti, 2020) Sebanyak 69\% konsumen berpindah menggunakan layanan ini untuk bertransaksi kebutuhan sehari-hari. Bahkan peningkatan sebesar $65 \%$ juga terjadi dalam pengunaan dompet digital, sebagai alat transaksi pembelian tersebut.

Selain itu E-Commerce di Indonesia diprediksi oleh perusahaan konsultan manajemen McKinsley telah diprediksi akan berkembang pada angka USD \$ 55 - \$ 65 miliar pada tahun 2022 (Rakhmawati et al., 2021). Hal tersebut menjadikan E-Commerce sebagai kekuatan baru dalam sektor ekonomi. E-Commerce didukung dengan kehadiran platform atau aplikasi belanja online sebagai media jual-beli online. Di Indonesia sendiri terdapat berbagai perusahaan E-Commerce berbasis aplikasi dengan jumlah pengguna terbanyak yakni Shopee, Tokopedia, Lazada, Bukalapak, dan Blibli dengan pengguna tertinggi sebesar 97 juta pengguna. Persaingan antar perusahaan ini juga sangat ketat, setiap perusahaan berlomba-lomba meningkatkan jumlah konsumen. Ada berbagai strategi yang dilakukan perusahaan dalam memengaruhi keputusan pembelian konsumen, strategi yang umum dilakukan adalah dengan melakukan program promosi yang menarik dan menjaga kualitas barang.

Beberapa riset terdahulu membuktikan bahwa promosi mampu mempengaruhi keputusan pembelian konsumen, salah satu diantaranya adalah riset dari (Devi, 2019) yang berjudul "Pengaruh Kualitas Produk, Harga dan Promosi terhadap Keputusan Pembelian pada Marketplace Shopee". Kebaruan dalam riset terletak pada perbedaan variabel X yaitu promosi, harga, dan kualitas barang sedangkan dalam riset ini variabel $\mathrm{X}$ menggunakan fitur aplikasi sedangkan persamaan dalam kedua riset adalah pada variabel Y yaitu keputusan pembelian serta sama-sama meriset mengenai E-Commerce. Fitur yang terdapat dalam aplikasi juga merupakan salah satu aspek utama yang dapat digunakan sebagai instrumen guna meningkatkan keputusan pembelian. Fitur aplikasi adalah salah satu bagian dari bentuk pelayanan terhadap konsumen sehingga menjadi penting untuk diperhatikan. Riset ini menguji adanya pengaruh fitur aplikasi terhadap keputusan pembelian konsumen dalam ECommerce. Berdasarkan paparan masalah penelitian yang telah ditelah diuarikan, maka dikembangakan hipotesis H1: Fitur Aplikasi E-Commerce berpengaruh positif terhadap keputusan pembelian konsumen dalam jual beli-online. Sasaran dari riset ini adalah perusahaan yang bergelut di bidang E-Commerce, harapannya riset ini dapat menjadi referensi baru bagi perusahaan tersebut.

\section{METODE PENELITIAN}

Penelitian ini menggunakan pendekatan kuantitatif, yaitu jenis penelitian yang memakai angka yang kemudian dianalisis menggunakan alat uji statisik untuk menjawab hipotesis yang telah diajukan. Penelitian ini menggunakan uji regresi linear sederhana dengan uji prasyarat berupa uji validitas, uji reliabilitas, uji normalitas, dan uji lineritas yang harus dipenuhi. Adapun teknik pengambilan data dengan metode penyebaran kuesioner 
online kepada sebanyak 47 responden mahasiswa Universitas Jember yang memiliki aplikasi market place.

\section{HASIL DAN PEMBAHASAN \\ Fitur dan Keputusan Pembelian}

Fitur menurut KBBI adalah fungsi, antarmuka atau kemampuan yang khusus dari perangkat keras atau perangkat lunak pada perangkat komputer. Dari pengertian tersebut dapat dikatakan bahwa fitur dalam sebuah aplikasi merupakan kemampuan yang didesain khusus dalam menjalankan sebuah aplikasi. Fitur-fitur aplikasi ibarat organ yang saling bekerjasama dan menjadi inti dari aplikasi tersebut. Keputusan pembelian menurut Kotler merupakan tahap-tahap yang dilakukan konsumen sebelum memutuskan membeli sebuah produk. Tahapan ini mencakup pengenalan kebutuhan, pencarian informasi, penilaian alternatif, keputusan pembelian, dan perilaku pasca pembelian.

\section{Karakteristik Responden}

Responden dalam penelitian ini dipilih dengan teknik purposive sampling, yaitu memilih responden dengan kriteria mahasiswa di kalangan Universitas Jember yang telah memiliki satu atau lebih akun aplikasi belanja online (Shopee, Lazada, Bukalapak, Tokopedia, JD.id, dan lain-lain). Responden mengisi kuesioner online melalui google form yang telah diberikan. Adapun berikut ringkasan data karakteristik responden:

\section{Tabel 2.1 Ringkasan Data Karakteristik Responden}

\begin{tabular}{|l|l|lll|}
\hline No. & \multicolumn{1}{|c|}{ Karakteristik Responden } & \multicolumn{3}{|c|}{ Hasil Data } \\
\hline 1. & Asal fakultas & FEB & $:$ & 22 \\
& & FISIP & $:$ & 19 \\
& & FKIP & $:$ & 4 \\
& & FT & $:$ & 2 \\
& & Fakultas lain & $:$ & 0 \\
\hline 2. & Usia & $<18$ & $:$ & 2 \\
& & $18-23$ & $:$ & 45 \\
& & $>23$ & $:$ & 0 \\
\hline 3. & Lama pemakaian aplikasi & $1-2$ th & $:$ & 20 \\
& & $3-5$ th & $:$ & 24 \\
& & $>5$ th & $:$ & 3 \\
\hline 4. & Aplikasi yang sering dipakai & Shopee & $:$ & 42 \\
& & Tokopedia & $:$ & 4 \\
& & Lazada & $:$ & 1 \\
& & Aplikasi lain & $:$ & 0 \\
\hline
\end{tabular}

$*(\mathrm{n})=47$

Sumber: Data kuesioner diolah, 2021.

\section{Uji Validitas}

Uji validitas digunakan untuk menguji apakah atribut data dalam sebuah penelitian itu valid atau tidak (Sugiyono, 2008). Dalam kata lain atribut data dapat digunakan untuk mengukur sesuatu yang ingin diukur. Adapun jumlah responden yang digunakan dalam penelitian ini sebanyak $(\mathrm{n})=47$, maka dapat diketahui nilai $\mathrm{r}$ tabel pada tingkat signifikansi kesalahan 5\% sebesar 0,288. Dari hasil uji validitas dengan bantuan sotware SPSS ditemukan kedua item variabel Fitur Aplikasi Belanja Online (X) dan Keputusan Pembelian (Y) menunjukkan nilai $r$ hitung $>r$ tabel. Dengan begitu dapat disimpulkan semua atribut data kuesioner yang digunakan dalam penelitian ini valid.

\section{Uji Reliabilitas}

Uji reliabilitas dimaksudkan untuk mengetahui seberapa jauh hasil pengukuran yang dilakukan menunjukkan konsistensi apabila dilakukan uji ukur secara berulang-ulang terhadap objek yang sama (Notoatmodjo, 2005). Adapun data penelitian dikatakan reliabel jika nilai cronbach's alpha senilai > 0,6 (Ghozali, 2011).

Tabel 2.3 Hasil Uji Reliabilitas Variabel Fitur Aplikasi E-Commerce (X) 
Pengaruh Fitur E-Commerce Terhadap Keputusan Pembelian Konsumen di Masa Pandemi Covid-19

Reliability Statistics

Cronbach's AlphaN of Items

\begin{tabular}{l|l}
.798 & 12
\end{tabular}

Sumber: Data SPSS diolah, 2021

Berdasarkan hasil uji reliabilitas dengan sotware SPSS terhadap instrumen variabel Fitur Aplikasi Belanja Online $(X)$ yang terdiri dari 12 item pertanyaan menunjukkan hasil cronbach's alpha senilai $0,789>0,6$.

\section{Tabel 2.4 Hasil Uji Reliabilitas Variabel Keputusan Pembelian (Y) Reliability Statistics \\ Cronbach's AlphaN of Items \\ .729 12 \\ Sumber: Data SPSS diolah, 2021}

Sedangkan dalam uji reliabilitas terhadap instrumen Keputusan Pembelian (Y) yang terdiri dari 12 item pertanyaan menunjukkan hasil cronbach's alpha senilai 0,729 >0,6. Sehingga dengan begitu dapat dikatakan bahwa kedua variabel, yaitu Fitur Aplikasi Belanja Online (X) dan Keputusan Pembelian (Y) dengan masing-masing memiliki atribut 12 item pertanyaan bersifat reliabel.

\section{Uji Normalitas}

Uji normalitas digunakan untuk mengukur apakah dalam model persamaan regresi, yaitu variabel independen dan variabel dependen memiliki distribusi normal atau tidak (Ghozali, 2011). Dalam uji normalitas, suatu data dapat dikatakan memiliki distribusi normal jika nilai signifikansi > 0,05 (Priyatno, 2009). Adapun dalam uji normalitas terhadap atribut data dari item pertanyaan yang terdiri dari variabel Fitur Aplikasi Belanja Online (X) dan variabel Keputusan Pembelian (Y) menggunakan uji lilifors dengan melihat nilai pada tabel kolmogorov-smirnov.

Tabel 2.5 Hasil Uji Normalitas One-Sample Kolmogorov-Smirnov Test

\begin{tabular}{lll} 
& & Unstandardized Residual \\
\hline $\mathrm{N}$ & & 47 \\
Normal Parameters & Mean & .0000000 \\
Most Extreme Differences & Std. Deviation & 4.63881324 \\
& Absolute & .114 \\
& Positive & .114 \\
Test Statistic & Negative & -.051 \\
Asymp. Sig. (2-tailed) & & .114 \\
\hline
\end{tabular}

Sumber: Data SPSS diolah, 2021

Berdasarkan hasil uji normalitas dengan sotware SPSS menghasilkan nilai signifikansi pada tabel kolmogorov-smirnov senilai 0,137 >0,05, denagn demikan dapat dikatakan bahwa data yang digunakan dalam penelitian ini, yaitu atribut data dari item pertanyaan variabel Fitur Aplikasi Belanja Online (X) dan Keputusan Pembelian (Y) berkontribusi normal dan bisa digunakan untuk perhitungan analisis regresi sederhana.

\section{Uji Linearitas}

Uji linearitas bertujuan untuk menguji apakah persamaan model regresi antara variabel independen dengan variabel dependen memiliki kecocokan atau tidak (Ghozali, 2011). Dua variabel dapat dikatakan mempunyai hubungan yang linear secara signifikan jika nilai signifikansi pada deviation from linearity > 0,05 (Nabila \& Isroah, 2019). 
Tabel 2.6 Hasil Uji Linearitas ANOVA Table

\begin{tabular}{llllllr} 
& & & Sum & of Mean & \\
& & & Squares & df Square & F & Sig. \\
\hline Keputusan Pembelian * FiturBetween & (Combined) & 632.769 & 1737.222 & 1.466 .178 \\
Aplikasi E-Commerce & Groups & Linearity & 379.464 & 1379.464 & 14.941 .001 \\
& & Deviation & from253.305 & 1615.832 & .623 & .839 \\
& Linearity & & & & \\
\multicolumn{2}{l}{$\begin{array}{l}\text { Within Groups } \\
\text { Total }\end{array}$} & 736.550 & 2925.398 & \\
\hline
\end{tabular}

Sumber: Data SPSS diolah, 2021

Dari hasil uji linearitas menggunakan sotware SPSS diketahui nilai deviation from linearity senilai 0,839 >0,05, sehingga dapat disimpulkan bahwa terdapat hubungan yang linear secara signifikan antara variabel Fitur Aplikasi E-Commerce (X) dengan variabel Keputusan Pembelian (Y).

\section{Analisis Uji Regresi Linear Sederhana}

Analisis uji regresi linear sederhana mempunyai beberapa fungsi, salah satunya adalah ditujukan untuk melakukan prediksi terhadap variabel dependen (Y) (Smadi dan AbuAfouna, 2012). Selain itu, dalam penelitian ini uji analisis regresi linear sederhana juga digunakan untuk menjawab $\mathrm{H} 1$ yang telah diajukan. Adapun dasar pengambilan keputusan uji regresi dilakukan dengan cara membandingkan nilai signifikansi dengan nilai probabilitas. Jika nilai signifikansi $<0,05$ artinya terdapat pengaruh antara variabel independen $(\mathrm{X})$ dengan variabel dependen $(Y)$.

Tabel 2.7 Hasil Uji Regresi Linear Sederhana Konstant

\begin{tabular}{lllll}
$\mathrm{a}$ & Koef Regresi & R Square & thitung & Sig \\
\hline 21.141 & .579 & .277 & 3.324 & .000 \\
\hline
\end{tabular}

Sumber: Data SPSS diolah, 2.021

Dari tabel 2.7 dapat diketahui persamaan regresi sebagai berikut:

$\mathrm{Y}=\mathrm{a}+\mathrm{bX}$

$\mathrm{Y}=21,141+0,579 \mathrm{X}$

Sehingga dari tabel 2.7 dan persamaan regresi sebelumnya dapat ditarik kesimpulan sebagai berikut:

1. Konstanta sebesar 21,141 memiliki arti bahwa nilai konsisten variabel Keputusan Pembelian (Y) sebesar 21,141

2. Koefisien regresi sebesar 0,579 menyatakan bahwa setiap penambahan $1 \%$ nilai variabel Fitur Aplikasi E-Commerce (X) menyebabkan penambahan sebesar 0,579 terhadap variabel Keputusan Pembelian (Y)

3. Berdasarkan nilai signifikansi pada tabel 2.7 diperoleh nilai signifikansi $0,000<$ 0,005, maka dapat disimpulkan bahwa variabel Fitur Aplikasi E-Commerce (X) berpengaruh positif terhadap Keputusan Pembelian (Y)

4. Dengan melihat hasil nilai signifikansi sebesar $0,000<0,05$, maka H1 diterima 
Pengaruh Fitur E-Commerce Terhadap Keputusan Pembelian Konsumen di Masa Pandemi Covid-19 5. Nilai koefisien determinan (KD) sebesar 0,277 yang menunjukkan bahwa Keputusan Pembelian (Y) dipengaruhi oleh Fitur Aplikasi E-Commerce (X) sebesar 27,7\%, sedangkan $72,3 \%$ dipengaruhi oleh faktor lain.

\section{Ulasan Perbaikan Fitur E-Commerce}

Sejauh ini aplikasi yang paling unggul adalah aplikasi Shopee (berdasarkan riset IPrice) dengan jumlah pengguna sebesar 97,3 juta pada tahun 2020. Selain itu dari hasil riset yang dilakukan penulis, sebanyak $89 \%$ responden menggunakan aplikasi Shopee. Sebanyak 85,1\% responden menyatakan fitur yang dimiliki Shopee paling lengkap diantara aplikasi serupa lainnya, ada beberapa fitur yang tidak dimiliki oleh aplikasi lain, hal tersebut merupakan salah satu keunggulan dari salah satu aplikasi. Memperbaiki kelengkapan dan juga inovasi pada fitur aplikasi dapat menjadi langkah strategis bagi perusahaan E-Commerce yang berbasis pada aplikasi untuk menarik minat konsumen dalam persaingan pasar yang semakin ketat.

Fitur aplikasi yang tersedia dalam aplikasi E-Commerce juga berperan dalam memberikan branding bagi perusahaan E-Commerce. Citra yang ditawarkan perusahaan tak lain harus bisa mengikat minat pengguna untuk menggunakan aplikasi tersebut. Dalam upaya ini terlebih dahulu perusahaan E-Commerce perlu mengetahui karakteristik dari pengguna. Maka dari itu, perusahaan dapat menganalisis lalu lintas transaksi dalam aplikasi ECommerce yang tengah dipakai pengguna. Misalnya perusahaan ingin melihat apakah metode pembayaran yang ditawarkan saat ini sudah mampu memberikan kemudahan kepada pengguna atau tidak. Dalam hal ini, perusahaan dapat melihat feedback dari pengguna terkait apresiasi, kritik, maupun saran yang diberikan yang berkaitan dengan pilihan metode pembayaran yang tersedia. Dengan begitu maka perusahaan dapat melihat apa yang kurang dan bisa merespon hal tersebut dengan rilis update fitur aplikasi untuk menjawab permasalahan yang ada.

\section{PENUTUP}

Berdasarkan analisis yang telah dilakukan dari hasil kajian literatur terdahulu serta riset yang dilakukan secara sistematis maka dapat ditarik kesimpulan bahwa perusahaan ECommerce yang berbasis aplikasi harus mempersiapkan strategi terbaiknya untuk meningkatkan transaksi atau keputusan pembelian konsumen. Salah satu langkah strategis yang mungkin diimplementasikan adalah dengan memperbaiki fitur yang terdapat dalam aplikasi. Fitur yang terdapat dalam sebuah aplikasi E-Commerce memberikan pengaruh yang signifikan yang bersifat positif terhadap keputusan pembelian konsumen, sehingga semakin baik dan menarik fitur yang dimiliki sebuah aplikasi maka keputusan pembelian konsumen akan semakin meningkat. Nilai KD sebesar 0,277, berarti Keputusan Pembelian (Y) dipengaruhi oleh Fitur Aplikasi E-Commerce (X) sebesar 27,7\%, sedangkan 72,3\% dipengaruhi oleh faktor lain. Berikut adalah rekomendasi yang diberikan penulis berdasarkan hasil riset:

1. Perusahaan E-Commerce harus memperhatikan kelengkapan fitur yang tersedia dalam aplikasi

2. Perusahaan E-Commerce dituntut untuk selalu berinovasi dalam menciptakan fiturfitur aplikasi baru

3. Penelitian selanjutnya terkait analisis kepuasan pengguna aplikasi E-Commerce untuk menentukan rilis update fitur yang sesuai dengan kebutuhan pengguna

4. Pendanaan investasi dari pihak luar untuk mendukung perkembangan perusahaan ECommerce

\section{DAFTAR PUSTAKA}

Kusumastuti, Anngit Dyah. "Pengaruh Pandemi Covid-19 Terhadap Eksistensi Bisnis Umkm Dalam Mempertahankan Business Continuity Management (BCM)." Jurnal Administrasi Bisnis 
Fisipol Unmul 8, no. 3 (2020): 224-232.

Devi, Lenggang Kurnia Intan. "Pengaruh kualitas produk, harga dan promosi terhadap keputusan pembelian pada marketplace Shopee (studi kasus pada mahasiswa di Surabaya)." PhD diss., UIN Sunan Ampel Surabaya, 2019.

Rakhmawati, Nur Aini, Alvin Edgar Permana, Arvy Muhammad Reyhan, and Hidayattul Rafli. "ANALISA TRANSAKSI BELANJA ONLINE PADA MASA PANDEMI COVID-19." Jurnal Teknoinfo 15, no. 1 (2021): 32-37.

Notoatmodjo, Soekidjo. "Metodologi penelitian kesehatan." (2012).

Sugiyono. Metode penelitian pendidikan:(pendekatan kuantitatif, kualitatif dan R \& D). Alfabeta, 2008.

Ghozali, Imam. Aplikasi Analisis Multivariate dengan Program IBM SPSS 19. Universitas Diponegoro: Semaran, (2011).

Priyatno, Duwi. 5 Jam Belajar Olah Data dengan SPSS. Yogyakarta: Elex Media Komputindo, 2009.

Smadi, Abdullah A., and Nour H. Abu-Afouna. "On Least Squares Estimation in a Simple Linear Regression Model with Periodically Correlated Errors: A Cautionary Note." Austrian Journal of Statistics 41, no. 3 (2012): 211-226.

Nabila, Zahra Durah, and Isroah Isroah. "Pengaruh Kewajiban Moral Dan Lingkungan Sosial Terhadap Kepatuhan Wajib Pajak Orang Pribadi Pengusaha." Nominal: Barometer Riset Akuntansi dan Manajemen 8, no. 1 (2019): 47-58. 